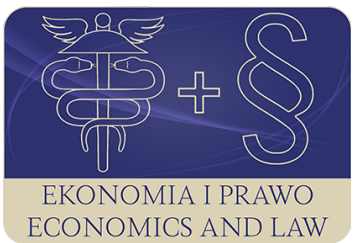

EKONOMIA I PRAWO. ECONOMICS AND LAW

Volume 20, Issue 2, June 2021

p-ISSN 1898-2255, e-ISSN 2392-1625

www.economicsandlaw.pl

ORIGINAL ARTICLE

received 06.10.2020; revised 20.06.2021; accepted 30.06.2021

Citation: Pondel, H. (2021). An attempt to evaluate the level of sustainable development in European Union countries. Ekonomia i Prawo. Economics and Law, 20(2), 383-399. https://doi.org/10.12775/EiP.2021.023.

\title{
An attempt to evaluate the level of sustainable development in European Union countries
}

\author{
HANNA PONDEL \\ Poznań University of Economics and Business, Institute of Economics, Department \\ of Macroeconomics and Development Research, al. Niepodległości 10, 61-875 Poznań, Poland \\ $\square$ hanna.pondel@ue.poznan.pl \\ D orcid.org/0000-0002-0107-5552
}

\begin{abstract}
Motivation: Sustainable development is a concept of development that arouses keen interest of various entities, is unprecise in many of its assumptions, undoubtedly applicable for the contemporary civilisation as well as the future generations, with effects difficult to measure and interpret, and constitutes a considerable research challenge. The research on the sustainability level of particular countries or regions have still been insufficient, as well as, due to varying research methods and research scopes, difficult to compare and causing difficulties in clear determination of the scale and progress in implementing the assumptions of this concept of development.

Aim: To evaluate the level of sustainable development in European Union countries in 2009 and 2018 with the application of the taxonomic method.

Results: In the vast majority of European Union countries, the value of the synthetic sustainable development indicator was higher in 2018 as compared to 2009. Only in the case of three countries the value decreased. The improvement of the indicator was driven mainly by the economic aspect. When evaluating the sustainable development level of European Union countries in 2009 and 2018, it may be claimed that each time the majority of countries noted a low level of sustainable development: a low and very low synthetic sustainable development indicator was demonstrated by $67 \%$ and $56 \%$ respectively of the entities under evaluation. In the group of countries with a very high aggregate indicator, the changes in 2018 as compared to 2009 were not significant; only the Neth-

erlands and Slovenia were in the group of countries with a high synthetic sustainable development indicator (in 2018 — with a very high indicator). Certainly, it should be seen
\end{abstract}


as positive that the group of countries with a very low aggregate indicator shrank considerably: from 17 in 2009 to eight in 2018. Among the countries representing that group in 2018 were only those which belonged to it also in 2009. As results from the conducted analysis, the countries which have attained a very high or high level of sustainable development maintain this status.

Keywords: sustainable development; European Union; level of sustainable development; taxonomic method

JEL: Q01; Q56

\section{Introduction}

The dynamics of changes occurring in the arena in which economic entities operate require goals and rules of operation to be revised. The goal of economic operations, i.e. to maximise profits, still remains up to date, but the definition of maximum profits changes and, above all, new methods and measures to achieve this goal appear.

For several tens of years now, the concept of sustainable development has been arousing fairly keen interest. Sustainable development seems to be an attractive alternative to traditional concepts of development as it takes into consideration the social, economic and environmental aspect of activities as well as the needs of the present and the future generations alike, it integrates activities of various individuals and entities and provides for equal chances to satisfy the needs of various communities. Although the assumptions underlying sustainable development seem to prove that such a development trend is practical in the present realities of life, it needs to be noted that it has both avid supporters and opponents. The critics point to the fact that the definition of sustainable development is inaccurate, the translation of the mere term "sustainable development" into Polish is under constant discussion, there are no unified standards of monitoring the progress in implementing the rules of sustainable development (including varying approaches to the analysis of indicators), lack of data for comparative analyses and progress monitoring, or discussions whether sustainable development is an idea, a concept or already as much as a theory of development.

Zimniewicz (2016, pp. 62-68) described sustainable development as "a beautiful vision of the world", yet "a vision without a chance to be realised". To justify his opinion, the said author analyses corporate practices, among which he counts the following: constant pursuit of profit, greed, disregarding moral norms and the sense of responsibility for others and for the condition of the natural environment (often pretending it is just otherwise), delocalisation of manufacturing and services, delocalisation of waste, overexploitation of natural resources. Additionally, difficulties in implementing sustainable development assumptions are augmented by problems with predicting the future (e.g. the needs of the future generations) and climate changes (discrepancies in estimates resulting from different mathematical models). The opinions of the author 
of a fairly radical approach to sustainable development may be argued in many aspects, however, it may not be denied that there are many barriers and problems in the face of which the concept in question is not being implemented completely according to its assumptions. And yet, is it truly fair to claim that sustainable development is a vision with no chance for realisation? At least, partial realisation? Does such an approach not rule out attempts to adapt activities of individuals and entities to the requirements posed by the contemporary world? Even if all, or the majority of, sustainable development rules are impossible to be put into practice, it is certainly worth trying.

This paper is aimed at evaluating the level of sustainable development in European Union countries in 2009 and 2018. Such a research goal is certainly not an easy one due to methodological issues, difficulties with the choice of indicators or problems with interpreting the results. European Union and its member states, however, are an interesting area of research in this regard, if only due to the aspirations of the Community to be a global leader, e.g. in the field of climate action.

\section{Literature review}

The title of this paper underlines it is an attempt to evaluate the level of sustainable development in European Union countries; one of many undertaken by numerous researchers. This particular concept of development demonstrates definitely better developed monitoring of its indicators, which indicators may and do constitute a basis for measuring the extent of sustainability. Publications, reports and other papers released by Eurostat refer to various groups of indicators; however, they often describe just one aspect of sustainable development rather than several of them in aggregate. An example of a comprehensive approach to sustainable development indicators is a report by Eurostat (2019d) Sustainable development in the European Union: monitoring report on progress towards the SDGs in an EU context. Progress in sustainable development in its particular aspects is reflected in information presented e.g. in Eurostat publications, such as Eurostat review on national accounts and macroeconomic indicators (economic aspect: Eurostat, 2019c), Energy, transport and environment statistics (environmental aspect: Eurostat, 2019b), Ageing Europe: looking at the lives of older people in the EU (social aspect: Eurostat, 2019a), or in those of the European Environment Agency, e.g. Air quality in Europe (environmental and social aspects: (EEA, 2019a), The European environment: state and outlook 2020: knowledge for transition to a sustainable Europe (environmental aspect: EEA, 2019b). Indicator-based monitoring of sustainable development goals is also conducted by the Polish Central Statistical Office, as well as many other institutions representing various areas of socio-economic life.

Because of the multitude of indicator classifications as well as varying approaches to the problem presented by institutions maintaining indicator databases, also the attempts to measure the level of sustainability vary from one 
to another to a great extent. An example of such an attempt undertaken for European Union countries is an analysis by Drastichová (2014) based on a macro-economic indicator of sustainable development proposed by the World Bank, i.e. adjusted net savings. Another assessment of sustainable development in EU countries was conducted by Martin \& Carnero (2019) with the application of a multi-criteria model developed with the use of the multi-criteria analytic hierarchy process (AHP) technique. A different approach to the measurement of sustainable development was proposed by Kovačič (2017), who determined correlations between various aspects of sustainable development with the use of the Spearman's rank correlation coefficient. The multitude of approaches to measuring sustainable development is further demonstrated in research by Georgescu \& Herman (2019), who based their analyses on the gross domestic product (GDP) per capita (in purchasing power standards (PPS) as a percentage of EU-28 average GDP=100\%), the Human Development Index (HDI), the Europe 2020 Competitiveness Index and the Inclusive Development Index (IDI), or the research of Kotosz (2012) which focused on alternatives to the GDP indicator due to the latter's limitations as seen by the author. Balcerzak \& Pietrzak (2017) proposed to use the methodology of structural equation modelling (SEM) in evaluating sustainable development in EU, which covers factor analysis and path analysis, both applied in econometrics. A method based on taxonomic quantitative methods was applied in the analyses by Głodowska (2016) and Klonowska-Matynia \& Sasin (2015). The latter authors used indicators selected by the European Commission for the evaluation of sustainable development in EU countries and included in the Europe 2020 Strategy, for an attempt to create a synthetic indicator of development. Although the taxonomic method is used also in this paper, the analysis assumptions, the indicators used and the manner to conduct the research show that even if the same method is used, the analysis itself and the results and their interpretation may vary.

\section{Methods}

This paper covers an analysis and evaluation of the sustainable development level in European Union countries. The object of the research are all EU countries, whereas the time range covers the years 2009 and 2018. In the analysis of the research problem the taxonomic method (linear ordering method) was applied, which allows to select countries similar in terms of the attributes investigated and to group them into regions with similar development conditions (Nowak, 2003, p. 203). The indicators used in the analysis are the author's own choice and just one of many options to solve the research problem.

One of the key stages of the applied research method is proper selection of diagnostic variables. Reporting sustainable development is based on many indicators, but these may not always be used when specific assumptions are adopted for the analysis; this entails a need to use only selected attributes that are, what is most important, available for all researched entities. 
The task was carried out with the use of data available in the Eurostat (2020) database. The variables were identified based on substantive premises. To assess whether potential considered variables may be useful, Pearson correlation coefficient and coefficient of variation were employed. The set of variables selected for the research and their nature is presented in Table $1 .{ }^{1}$ Basic descriptive statistics measures of the diagnostic variables to be further analysed are presented in Table 2. It shows that the greatest variation in 2009 was demonstrated by adult participation in learning, whereas in 2018 it was the long-term unemployment rate and the self-reported unmet need for medical examination and care. The slightest variation both in 2009 and 2018 was observed in the indicator regarding people at risk of poverty or social exclusion.

Due to various units and differentiated range of values of the variables, they were normalised in the analysis with the use of zeroed unitarisation. For this purpose, the following formulas were employed (Krzyminiewska \& Pondel, 2016, p. 196; Olejnik, 2006, p. 198-199):

- for stimulants:

$$
z_{i j}=\frac{x_{i j}-\min x_{i j}}{\max x_{i j}-\min x_{i j}}
$$

- for destimulants:

$$
z_{i j}=\frac{\operatorname{maxx}_{i j}-x_{i j}}{\max x_{i j}-\min x_{i j}}
$$

where:

$z_{i j}$ - normalised value of the $j$-th variable in the $i$-th country;

$x_{i j}$ - value of the $j$-th variable in the $i$-th country.

The set of normalised diagnostic variables was used to determine a synthetic development indicator (TMRZ), i.e. a taxonomic indicator of sustainable development of European Union countries for the particular aspects and an aggregate indicator, for 2009 and 2018. ${ }^{2}$ For this purpose, the non-model-based linear ordering method was employed: ${ }^{3}$

${ }^{1}$ In the beginning, 18 variables were pre-selected for the research. Eight variables were ultimately excluded from the analysis due to the correlation among variables and the relation of the coefficient to its critical value. For the coefficient of variation, 10\% was adopted as the critical value, which entailed exclusion of five attributes failing to meet the criterion of sufficient variability.

2 The synthetic development indicator takes values from the interval $[0,1]-$ the higher the indicator value, the better the situation of the researched entity (Krzyminiewska \& Pondel, 2016, p. 197; Łogwiniuk, 2011, p. 15).

3 Non-model-based formulas of aggregation of variables usually consist in averaging normalised values of variables $Z_{\mathrm{ij}}$ in the cross section of variables, taking into account weight factors. Among a multitude of weight systems, empirical research usually uses constant weights, which means that each variable in the taxonomic analysis has the same signifi- 


$$
\operatorname{TMRZ}_{t}=\frac{1}{m} \sum_{j=1}^{m} Z_{i j}
$$

where:

$t$ - ordinal number of the particular country;

$j$ - ordinal number of the diagnostic variable;

$m$ - total number of diagnostic variables.

The results of the linear ordering were a basis for the classification of countries into homogeneous groups, from the perspective of the achieved level of sustainable development in the particular aspects and in aggregate, in both analysed years. The country classification was based on the mean value of the synthetic indicator (TMRZ $_{\text {mean }}$ for the entire population examined) and the standard deviation from the mean $(\sigma)$. For the indicators specifying the sustainable development level in aggregate and in the economic, social and environmental aspect, four intervals of the indicator value were set to which the following groups of countries were assigned:

- with a very high development level,

- with a high development level,

- with a low development level,

- with a very low development level. ${ }^{4}$

The results attained allowed to determine which aspect of sustainable development impairs the sustainability level of a country (Krzyminiewska \& Pondel, 2016, p. 197).

\section{Results}

As shown by the analysis, in as many as 23 out of 26 European Union countries, ${ }^{5}$ the value of the aggregate synthetic sustainable development indicator was higher than in 2009, and only in the case of three countries the value decreased (a decrease was noted in Estonia, Greece and Slovenia). The improvement in the indicator value was driven mainly by the economic component: the synthetic sustainable development indicator in this aspect grew in 22 out of $23 \mathrm{EU}$ countries in which the aggregate indicator improved in 2018 as com-

cance. This is in accordance with the essence of sustainable development, which assumes the equality of the economic, social and environmental aspect (Bazarnik et al., 1992, p. 122, 131; Krzyminiewska \& Pondel, 2016, p. 197).

${ }^{4}$ Countries with a very high development level: (TMRZ $\left.{ }_{\text {mean }}+\sigma\right)$ and more; countries with a high development level: $\left(\mathrm{TMRZ}_{\text {mean }}\right)$ up to $\left(\mathrm{TMRZ}_{\text {mean }}+\sigma\right)$; countries with a low development level: $\left(T M R Z_{\text {mean }}\right)$ up to $\left(\mathrm{TMRZ}_{\text {mean }}-\sigma\right)$; countries with a very low development level: $\left(\mathrm{TMRZ}_{\text {mean }}-\sigma\right)$ and less.

5 The analysis of the sustainable development level of EU countries in 2009 was exclusive of Croatia, which at the time was not an EU member state, and Bulgaria, for which the aggregate indicator and the economic indicator for 2018 could not have been calculated due to the lack of data. 
pared to 2009. Only in the case of Cyprus, the indicator slightly decreased, and the increase in the aggregate indicator was driven by significant improvement in the environmental aspect, particularly with regard to the share of renewable energy in gross final energy consumption (Table 3).

With regard to the social aspect, the sustainable development indicator grew in 2018 as compared to 2009 for 15 out of 27 EU countries under analysis. The most notable positive change was observed in Bulgaria, Latvia, Poland and Romania, which is to say, Central and Eastern European countries. This change was driven mainly by an improvement in the self-reported unmet need for medical examination and care (Table 3). To a large extent, it was probably related to the development of the private medical care sector and improved abilities of part of the societies of the said countries to use this sector of healthcare.

In the case of the environmental sustainable development synthetic indicator, in 14 out of 27 European Union countries for which the analysis was viable, the value of the indicator grew, and the biggest increase was observed in Denmark (Table 3). This is by no means a surprise: Denmark has been for years consequently undertaking actions for the environment, which is also shown by considering this country most environmentally-friendly in the Environmental Performance Index for 2020 (Grzelak, 2020), or an increase of the share of renewable energy in gross final energy consumption, i.e. 19.95\% in 2009 as compared to $35.71 \%$ in 2018 (Eurostat, 2020).

When evaluating the sustainable development level of European Union countries in 2009 and 2018, it may be claimed that each time the majority of countries noted a low level of sustainable development: a low and very low synthetic sustainable development indicator was noted for approximately $67 \%$ and $56 \%$ of the investigated entities respectively (Table 4).

As results from the conducted analysis of source data and the determined synthetic sustainable development indicators presented in Table 4, both the aggregate one and the specific ones, in 2009 the social aspect was the one that impaired the sustainability of EU countries to the largest extent: 18 out 0 f 27 investigated entities showed a low and very low level of development in this aspect. In 2018, the impairing factor was mainly the economic aspect (17 countries with a low and very low level of development).

Tables 4 and 5 show that in the group of countries with a very high level of the aggregate indicator, the changes in 2018 as compared to 2009 were not significant; only the Netherlands and Slovenia were in the group of countries with a high synthetic sustainable development indicator (in 2018 - with a very high indicator). Certainly, it should be seen as positive that the group of countries with a very low aggregate indicator shrank considerably: from 17 in 2009 to eight in 2018. Among the countries representing that group in 2018 were only those which belonged to it also in 2009. This means that these countries are in stagnation or negative trends in terms of the analysed variables. Let us note, however, that the typology of EU countries based on the sustainable de- 
velopment level could look differently, if the analysis was based on different indicators reflecting the particular aspects of sustainable development.

Based on the previous analyses, the researched countries were subject to ordering with regard to the synthetic sustainable development indicator based on three aspects: economic, social and environmental one. The results are presented in Table 6 and 7. The first place in the ranking of EU countries based on the sustainable development level according to the value of the analysed indicators for 2018 was taken by Sweden, both for the aggregate and the specific indicators for all three aspects. The top of the countries with a high sustainable development level was also occupied by Finland, Denmark and Austria. As much as the high position of the Nordic countries in the ranking is no surprise, such a surprise may be Latvia ranking second among the countries with the highest environmental indicator. The approach of Latvia to the environmental issues, including climate action, may seem, in principle, similar to the policy of the other countries of the region, its vision of measures, however, often differs from the vision of other countries (e.g. in terms of climate transformation). According to the data for 2018, the latest available ones, Latvia is the third EU country in terms of the share of renewable energy (approximately 35\%) in the energy mix. In January 2020, the Latvian government adopted a plan for energy and climate for 2021-2030 and a long-term strategy of climate neutrality by 2050. The roadmap of the measures includes limitation of greenhouse gas emissions, improvement of energy efficiency or creation of approximately 10 thousand jobs (Raś, 2020).

The results of the ordering of EU countries in terms of the socio-economic development level coincide with the results of research of other authors, e.g. Kozar (2016). ${ }^{6}$ Kozar (2016, p. 194) ordered the countries with three methods, using another (wider) set of variables, and he obtained the following results:

- for the method of Hellwig development model, the first four places were taken by: Sweden (1), Finland (2), Luxemburg (3) and Denmark (4);

- for the sum method, the first four places were taken by: Sweden (1), Luxemburg (2) Denmark (3) and Finland (4);

- for the rank method, the first four places were taken by: Sweden (1), Denmark (2), Luxemburg (3) and Finland (4).

The starting point for any measures aimed at sustainable development is the ability to fund them. In the ranking presented in Table 7, the first four countries with the highest value of the aggregate synthetic sustainable development indicator are the same countries raking first in terms of the economic indicator. The research allows to formulate the following rule: entities taking the highest positions in the ranking based on the aggregate indicator also take the highest

${ }^{6}$ Kozar (2016, p. 189) developed a ranking of EU countries in terms of their socio-economic development based on data for 2013. For this purpose, he used variables (indicators) proposed by the Polish Central Statistical Office to determine Poland's level of sustainable development. 
positions in the rankings based on the particular indicators, including the economic one.

\section{Conclusion}

This paper deals with an analysis of the level of sustainable development of European Union countries based on indicators specific for three aspects of this development. The indicators applied in the analysis and the adopted research method are own, subjective choice of the author, which may be disputable. The choice of diagnostic attributes was determined mainly by their availability for all the investigated entities and for the two analysed years. Expanding the range of variables would certainly allow for a more complex analysis, which, however, would require the reporting and monitoring of sustainable development implementation in the particular aspects to be rearranged, an issue discussed multiple times in different forums. A uniform set of indicators and methodology of measuring the sustainability level, including the creation of a universal measure in this area, is necessary in the context of the research applicability in the policies pursued both by the European Union as a whole and by its particular member states. Research undertaken by various representatives of the academia is certainly valuable, but its applicability has been, so far, insufficient.

As results from the conducted analysis, the countries which have attained a very high or high level of sustainable development maintain this status (the ranking of countries for 2009 and 2018). Sustainable development requires both financial means, as mentioned before, for implementing its goals and applying particular rules of operation, as well as increased awareness of the need to implement this concept of development. Nordic countries, such as Sweden, Denmark or Finland, as well as Austria, belong to the seven EU countries with the highest GDP per capita (in purchasing power standards) in 2018, i.e. 126, 127, 119 and 128 respectively. The conducted research also showed that the Community members at the top of the ranking based on the aggregate synthetic sustainable development indicator are also at the top of the rankings based on the particular development aspects, including the one based on the economic indicator. Furthermore, Nordic countries note increased environmental awareness among their inhabitants, and their lifestyle (connection to the nature) has been known worldwide for years. ${ }^{7}$ Also the Nordic welfare state model has been and remains something special in whole Europe, and certainly the most extended and advanced form of the state social care system (Prorok, 2013, p. 188). All the above-mentioned attributes of the Nordic countries, reinforced

${ }^{7}$ Sweden is a country which in 2025 wants to achieve $50 \%$ of multi-family buildings constructed from wood. This is aimed at meeting the demand for residential construction, considerable reduction of $\mathrm{CO}_{2}$ in the construction sector and creation of jobs outside of urban areas. For comparison, the production output of wooden houses from Poland is mainly exported, including to the Nordic countries (IRME, 2017). 
consequently for years, determine their domination in terms of the sustainable development level.

The conducted analysis of many variables representing various aspects of sustainable development showed a weak position of Poland with regard to the implementation of this development concept. Unfortunately, both in 2009 and in 2018 Poland belonged to the group of countries with a very low level of sustainable development. Poland is separated from the countries with a very high sustainable development level by a considerable development distance, which is shown by the GDP per capita value (in purchasing power standards), i.e. 71 in 2018, as well as by far positions taken in terms of the other indicators proposed in the analysis.

\section{References}

Balcerzak, A., \& Pietrzak, M. (2017). Sustainable development in the European Union in the years 2004-2013. In M.H. Bilgin, H. Danis, \& U. Can (Eds.), Regional studies on economic growth, financial economics and management (pp. 193-213). https://doi.org/10.1007/978-3-319-54112-9_12.

Bazarnik, J., Grabiński, T., \& Wojdacki, K.P. (1992). Taksonomiczne metody analizy przestrzennej struktury konsumpcji. In S. Mynarski (Ed.), Badania przestrzenne rynku i konsumpcji: przewodnik metodyczny (pp. 117-160). PWN.

Drastichová, M. (2014). Measuring sustainable development in the European Union using the adjusted net saving. In I. Honová, M. Hon, L. Melecký, \& M. Staníčková (Eds.), Proceedings of the 2nd international conference on European integration, 2, 87-101. Technical University of Ostrava.

EEA. (2019a). Air quality in Europe: 2019 report. Retrieved 09.03.2020 from https://www.eea.europa.eu/publications/air-quality-in-europe-2019.

EEA. (2019b). The European environment: state and outlook 2020: knowledge for transition to a sustainable Europe. Retrieved 09.03.2020 from https://www. eea.europa.eu/soer-2020.

Eurostat. (2019a). Ageing Europe: looking at the lives of older people in the EU. https://doi.org/10.2785/811048.

Eurostat. (2019b). Energy, transport and environment statistics. https://doi. org/10.2785/660147.

Eurostat. (2019c). Eurostat review on national accounts and macroeconomic indicators, 2. Retrieved 09.03.2020 from https://ec.europa.eu/eurostat/cros/ content/eurona_en.

Eurostat. (2019d). Sustainable development in the European Union: monitoring report on progress towards the SDGsin an EU context. https://doi.org/10.2785/44964.

Eurostat. (2020). Retrieved 11.08.2020 from https://ec.europa.eu/eurostat/ data/database.

Georgescu, M.-A., \& Herman, E. (2019). Productive employment for inclusive and sustainable development in European Union countries. Sustainability, 1l(6). https://doi.org/10.3390/sull061771. 
Głodowska, A. (2016). Sustainable development strategy and the effectiveness of its implementation in the European Union. Przedsiębiorczość i Zarządzanie, $17(10), 71-83$.

Grzelak, K. (2020). Ranking najbardziej przyjaznych środowisku państw: Dania na pierwszym, Polska - 37. Retrieved 15.08.2020 from https://www.focus. $\mathrm{pl} /$ artykul/ranking-najbardziej-przyjaznych-srodowisku-panstw-daniana-pierwszym-polska-37.

IRME. (2017). Budownictwo ekologiczne wyczarowane $z$ drewna. Retrieved 17.08.2020 from https://irme.pl/ budownictwo-ekologiczne-wyczarowane-z-drewna.

Klonowska-Matynia, M., \& Sasin, M. (2015). Zrównoważony rozwój krajów Unii Europejskiej: typologia krajów w kontekście Strategia Europa 2020. Annual Set The Environment Protection, 17, 771-791.

Kotosz, B. (2012). Measuring sustainable development at macro level. In I. Zentkova (Ed.), Global commodity markets: new challenges and the role of policy (pp. 707-712). Slovak University of Agriculture in Nitra.

Kovačič, A. (2017). European Union and sustainable indicators. Management of Sustainable Development Sibiu, 9(2), 19-29. https://doi.org/10.1515/ msd-2017-0018.

Kozar, Ł. (2016). Ranking krajów UE pod względem poziomu rozwoju społeczno-gospodarczego. Zeszyty Naukowe Szkoty Gtównej Gospodarstwa Wiejskiego w Warszawie: Problemy Rolnictwa Światowego, 16(31), 186-198.

Krzyminiewska, G., \& Pondel, H. (2016). Sustainable development of rural municipalities of the Wielkopolska Voivodship: an attempt at evaluation. Economic and Environmental Studies, 16(2), 191-206.

Łogwiniuk, K. (2011). Zastosowanie metod taksonomicznych $\mathrm{w}$ analizie porównawczej dostępu do infrastruktury ICT przez młodzież szkolną w Polsce. Economy and Management, 1, 7-23.

Martin, C.J., \& Carnero, C. (2019). Evaluation of sustainable development in European Union countries. Applied Sciences, 9(22), 4880. https://doi. org/10.3390/app9224880.

Nowak, L. (2003). Metody taksonomiczne. In H. Mruk (Ed.), Analiza rynku (pp. 203-211). PWE.

Olejnik, I. (2006). Wielowymiarowa analiza zróżnicowania przestrzennego rozwoju handlu w Polsce. In J. Mikołajczyk (Ed.), Handel: znaczenie we wspótczesnej gospodarce (pp. 195-202). Wyższa Szkoła Handlu i Usług.

Prorok, L. (2015). Doświadczenie północnoeuropejskie a polska polityka społeczna: uwagi na temat książki W. Anioła Szlak Norden: Modernizacja po skandynawsku. Przegląd Socjologiczny, 64(2), 187-199.

Raś, K. (2020). Polityka klimatyczna Eotwy. Retrieved 15.08.2020 from https:// www.pism.pl/publikacje/Polityka_klimatyczna_Lotwy.

Zimniewicz, K. (2016). Zrównoważony rozwój: wizja bez szans na realizację. Ekonomia i Środowisko, 3(58), 62-72. 


\section{Acknowledgements}

Author contributions: author has given an approval to the final version of the article.

Funding: this research was fully funded by the Ministry of Science and Higher Education subsidy for the research activity of the Poznan University of Economics and Business, Institute of Economics, Department of Macroeconomics and Development Research.

Note: the results of this study were presented at 9th Scientific Conference: Contemporary Economic Problems 'Thirty years of transformation' (September, 16, 2020, online, Poland). 


\section{Appendix}

Table 1.

List and nature of attributes taken into account when evaluating the level of sustainable development in European Union countries

\begin{tabular}{|c|c|c|}
\hline Item & Variable name & Variable nature \\
\hline \multicolumn{3}{|c|}{ economic dimension } \\
\hline $\mathrm{Xl}$ & long-term unemployment rate (\% of active population) & destimulant \\
\hline $\mathrm{X} 2$ & investment share of GDP (\% of GDP) & stimulant \\
\hline $\mathrm{X} 3$ & total general government revenue (\% of GDP) & stimulant \\
\hline \multicolumn{3}{|c|}{ social dimension } \\
\hline $\mathrm{X} 4$ & people at risk of poverty or social exclusion (\%) & destimulant \\
\hline X5 & adult participation in learning (\% of population aged 25 to 64 ) & stimulant \\
\hline X6 & $\begin{array}{l}\text { self-reported unmet need for medical examination and care (\% of population aged } 16 \\
\text { and over) }\end{array}$ & destimulant \\
\hline \multicolumn{3}{|c|}{ environmental dimension } \\
\hline $\mathrm{X} 7$ & greenhouse gas emissions per capita (tonnes of $\mathrm{CO}_{2}$ equivalent per capita) & destimulant \\
\hline $\mathrm{X} 8$ & share of renewable energy in gross final energy consumption (\%) & stimulant \\
\hline X9 & domestic material consumption per capita (tonnes) & destimulant \\
\hline $\mathrm{X} 10$ & area under organic farming (\% of utilised agricultural area) & stimulant \\
\hline
\end{tabular}

Source: Own preparation based on Eurostat (2020).

Table 2.

Basic measures and distribution of the variables adopted for the evaluation of the level of sustainable development in European Union countries

\begin{tabular}{|c|c|c|c|c|c|c|c|c|c|c|}
\hline \multirow{2}{*}{ Variable } & \multicolumn{2}{|c|}{ Mean } & \multicolumn{2}{|c|}{ Standard deviation } & \multicolumn{2}{|c|}{ Coefficient of variation } & \multicolumn{2}{|c|}{ Minimum value } & \multicolumn{2}{|c|}{ Maximum value } \\
\hline & 2009 & 2018 & 2009 & 2018 & 2009 & 2018 & 2009 & 2018 & 2009 & 2018 \\
\hline $\mathrm{Xl}$ & 2.70 & 2.00 & 1.13 & 1.27 & 0.42 & 0.64 & 0.60 & 0.70 & 6.50 & 13.60 \\
\hline $\mathrm{X} 2$ & 19.35 & 20.40 & 4.86 & 4.85 & 0.25 & 0.24 & 15.91 & 11.14 & 27.86 & 26.31 \\
\hline $\mathrm{X} 3$ & 43.15 & 45.05 & 8.56 & 8.98 & 0.20 & 0.20 & 30.30 & 25.40 & 53.70 & 53.40 \\
\hline $\mathrm{X} 4$ & 21.10 & 21.55 & 1.27 & 2.19 & 0.06 & 0.10 & 14.00 & 12.20 & 46.20 & 32.80 \\
\hline X5 & 13.90 & 11.55 & 9.62 & 4.31 & 0.69 & 0.37 & 1.60 & 0.90 & 31.40 & 31.40 \\
\hline X6 & 0.90 & 3.15 & 0.42 & 1.91 & 0.47 & 0.61 & 0.20 & 0.10 & 10.30 & 16.40 \\
\hline X7 & 11.10 & 9.15 & 1.41 & 2.33 & 0.13 & 0.26 & 5.40 & 5.40 & 25.80 & 20.30 \\
\hline X8 & 4.03 & 10.22 & 0.97 & 1.13 & 0.24 & 0.11 & 0.22 & 7.39 & 47.88 & 54.65 \\
\hline X9 & 12.28 & 10.16 & 3.94 & 2.56 & 0.32 & 0.25 & 8.16 & 8.11 & 32.03 & 34.60 \\
\hline $\mathrm{X} 10$ & 3.60 & 4.60 & 0.85 & 2.77 & 0.24 & 0.60 & 0.20 & 0.41 & 18.50 & 24.08 \\
\hline
\end{tabular}

Source: Own preparation. 
Table 3.

Values of the synthetic sustainable development indicator for European Union countries in 2009 and 2018

\begin{tabular}{|c|c|c|c|c|c|c|c|c|}
\hline \multirow[t]{2}{*}{ EU Country } & \multicolumn{2}{|c|}{$\begin{array}{l}\text { Economic indicator } \\
\left(\text { TMRZ }_{\text {economic }}\right)\end{array}$} & \multicolumn{2}{|c|}{$\begin{array}{l}\text { Social indicator } \\
\left(\text { TMRZ }_{\text {social }}\right)\end{array}$} & \multicolumn{2}{|c|}{$\begin{array}{l}\text { Environmental indi- } \\
\text { cator }\left(\mathrm{TMRZ}_{\text {mean }}\right)\end{array}$} & \multicolumn{2}{|c|}{$\begin{array}{l}\text { Aggregate indicator } \\
\left(\text { TMRZ }_{\text {general }}\right)\end{array}$} \\
\hline & 2009 & 2018 & 2009 & 2018 & 2009 & 2018 & 2009 & 2018 \\
\hline Belgium & 0.6304 & 0.8648 & 0.6508 & 0.5887 & 0.4074 & 0.4486 & 0.5629 & 0.6340 \\
\hline Bulgaria & 0.6009 & - & 0.0000 & 0.3140 & 0.4444 & 0.4281 & 0.3484 & - \\
\hline Czechia & 0.7003 & 0.8667 & 0.7150 & 0.7456 & 0.5047 & 0.5045 & 0.6400 & 0.7056 \\
\hline Denmark & 0.7855 & 0.8744 & 0.9198 & 0.8115 & 0.4510 & 0.5439 & 0.7188 & 0.7433 \\
\hline Germany & 0.4726 & 0.7854 & 0.6134 & 0.6392 & 0.4803 & 0.4670 & 0.5221 & 0.6305 \\
\hline Estonia & 0.5300 & 0.7533 & 0.5336 & 0.3414 & 0.5110 & 0.4426 & 0.5249 & 0.5124 \\
\hline Ireland & 0.3553 & 0.5665 & 0.5421 & 0.6106 & 0.2404 & 0.2609 & 0.3793 & 0.4793 \\
\hline Greece & 0.4055 & 0.2679 & 0.3722 & 0.2109 & 0.4824 & 0.5624 & 0.4200 & 0.3471 \\
\hline Spain & 0.3921 & 0.5325 & 0.6489 & 0.5446 & 0.5545 & 0.6029 & 0.5318 & 0.5600 \\
\hline France & 0.6332 & 0.8441 & 0.6098 & 0.7535 & 0.5089 & 0.5610 & 0.5840 & 0.7195 \\
\hline Croatia & - & 0.7103 & - & 0.4581 & - & 0.6463 & - & 0.6049 \\
\hline Italy & 0.5159 & 0.5872 & 0.4314 & 0.4540 & 0.5945 & 0.6790 & 0.5139 & 0.5734 \\
\hline Cyprus & 0.6345 & 0.6284 & 0.5377 & 0.5141 & 0.2314 & 0.3842 & 0.4679 & 0.5089 \\
\hline Latvia & 0.3698 & 0.6788 & 0.1439 & 0.3432 & 0.7950 & 0.7470 & 0.4362 & 0.5897 \\
\hline Lithuania & 0.3135 & 0.6160 & 0.4430 & 0.4255 & 0.6232 & 0.5477 & 0.4599 & 0.5297 \\
\hline Luxembourg & 0.5771 & 0.6779 & 0.7506 & 0.6925 & 0.1560 & 0.1626 & 0.4946 & 0.5110 \\
\hline Hungary & 0.5413 & 0.8509 & 0.4581 & 0.5883 & 0.5505 & 0.4719 & 0.5166 & 0.6370 \\
\hline Malta & 0.3844 & 0.6321 & 0.6133 & 0.6639 & 0.4744 & 0.4514 & 0.4907 & 0.5825 \\
\hline Netherlands & 0.6295 & 0.7360 & 0.8254 & 0.7907 & 0.4277 & 0.4166 & 0.6275 & 0.6478 \\
\hline Austria & 0.7443 & 0.8753 & 0.7416 & 0.7361 & 0.7448 & 0.7225 & 0.7436 & 0.7780 \\
\hline Poland & 0.4842 & 0.6707 & 0.3143 & 0.5269 & 0.4275 & 0.3515 & 0.4087 & 0.5164 \\
\hline Portugal & 0.4214 & 0.6203 & 0.5052 & 0.5764 & 0.5373 & 0.5691 & 0.4880 & 0.5886 \\
\hline Romania & 0.5244 & 0.5983 & 0.0816 & 0.2400 & 0.5208 & 0.4570 & 0.3756 & 0.4318 \\
\hline Slovenia & 0.6829 & 0.6960 & 0.7822 & 0.6513 & 0.5436 & 0.5627 & 0.6696 & 0.6367 \\
\hline Slovakia & 0.2219 & 0.6455 & 0.5760 & 0.5831 & 0.5530 & 0.5291 & 0.4503 & 0.5859 \\
\hline Finland & 0.7879 & 0.9179 & 0.7504 & 0.8047 & 0.4158 & 0.4737 & 0.6514 & 0.7321 \\
\hline Sweden & 0.7935 & 0.9315 & 0.7984 & 0.8775 & 0.7886 & 0.8025 & 0.7935 & 0.8705 \\
\hline United Kingdom & 0.3568 & 0.6094 & 0.7645 & 0.5500 & 0.4994 & 0.5052 & 0.5402 & 0.5549 \\
\hline UE-27/28 & 0.4936 & 0.7051 & 0.7076 & 0.5694 & 0.4534 & 0.4769 & 0.5516 & 0.5945 \\
\hline
\end{tabular}

Source: Own preparation. 


\section{Table 4.}

\section{European Union countries by the level of sustainable development}

\begin{tabular}{|c|c|c|c|c|}
\hline \multirow{2}{*}{$\begin{array}{l}\text { Synthetic sustainable } \\
\text { development } \\
\text { indicator }\end{array}$} & \multicolumn{2}{|c|}{2009} & \multicolumn{2}{|c|}{2018} \\
\hline & Indicator value & Number of countries & Indicator value & Number of countries \\
\hline \multicolumn{5}{|c|}{ Aggregate indicator $\left(T M R Z_{\text {genera }}\right)$} \\
\hline very high & above 0.5676 & 8 & above 0.6504 & 6 \\
\hline high & $0.5516-0.5676$ & 1 & $0.5945-0.6504$ & 6 \\
\hline low & $0.5356-0.5516$ & 1 & $0.5385-0.5945$ & 7 \\
\hline very low & below 0.5356 & 17 & below 0.5386 & 8 \\
\hline \multicolumn{5}{|c|}{ Economic indicator $\left(\mathrm{TMRZ}_{\text {economic }}\right)$} \\
\hline very high & above 0.6871 & 5 & above 0.9177 & 2 \\
\hline high & $0.4936-0.6871$ & 11 & $0.7371-0.9177$ & 8 \\
\hline low & $0.3001-0.4936$ & 10 & $0.5565-0.7371$ & 15 \\
\hline very low & below 0.3001 & 1 & below 0.5565 & 2 \\
\hline \multicolumn{5}{|c|}{ Social indicator $\left(\right.$ TMRZ $\left._{\text {social }}\right)$} \\
\hline very high & above 0.7880 & 3 & above 0.5968 & 12 \\
\hline high & $0.7076-0.7880$ & 6 & $0.5694-0.5968$ & 4 \\
\hline low & $0.6272-0.7076$ & 2 & $0.5420-0.5694$ & 2 \\
\hline very low & below 0.6272 & 16 & below 0.5420 & 10 \\
\hline \multicolumn{5}{|c|}{ Environmental Indicator (TMRZ $\left.Z_{\text {envirnmentrat }}\right)$} \\
\hline very high & above 0.5185 & 11 & above 0.5169 & 13 \\
\hline high & $0.4534-0.5185$ & 7 & $0.4769-0.5169$ & 2 \\
\hline low & $0.3883-0.4534$ & 6 & $0.4369-0.4769$ & 8 \\
\hline very low & below 0.3883 & 3 & below 0.4369 & 5 \\
\hline
\end{tabular}

Source: Own preparation.

Table 5.

\section{Typology of European Union countries by the level of sustainable development}

\begin{tabular}{|c|c|c|}
\hline \multirow{2}{*}{$\begin{array}{l}\text { Aggregate indicator } \\
\quad\left(\text { TMRZ }_{\text {general }}\right)\end{array}$} & \multicolumn{2}{|c|}{ Countries } \\
\hline & 2009 & 2018 \\
\hline very high & $\begin{array}{l}\text { Czechia, Denmark, France, the Nether- } \\
\text { lands, Austria, Slovenia, Finland, Sweden }\end{array}$ & $\begin{array}{l}\text { Czechia, Denmark, France, Austria, Finland, } \\
\text { Sweden }\end{array}$ \\
\hline high & Belgium & $\begin{array}{l}\text { Belgium, Germany, Croatia, Hungary, } \\
\text { the Netherlands, Slovenia }\end{array}$ \\
\hline low & United Kingdom & $\begin{array}{l}\text { Spain, Italy, Latvia, Malta, Portugal, Slova- } \\
\text { kia, United Kingdom }\end{array}$ \\
\hline very low & $\begin{array}{l}\text { Bulgaria, Germany, Estonia, Ireland, } \\
\text { Greece, Spain, Italy, Cyprus, Latvia, Lithu- } \\
\text { ania, Luxembourg, Hungary, Malta, Poland, } \\
\text { Portugal, Romania, Slovakia, }\end{array}$ & $\begin{array}{l}\text { Estonia, Ireland, Greece, Cyprus, Lithuania, } \\
\text { Luxembourg, Poland, Romania }\end{array}$ \\
\hline
\end{tabular}

Source: Own preparation. 
Table 6.

Level of development sustainability of European Union countries, as per results of the linear ordering based on the aggregate indicator

\begin{tabular}{|c|c|c|c|c|}
\hline Country & 2009 & 2018 & Mean value & Position in the European Union \\
\hline Belgium & 9 & 10 & 9.5 & 9 \\
\hline Bulgaria & 27 & 27 & 27.0 & 27 \\
\hline Czechia & 6 & 6 & 6.0 & 5 \\
\hline Denmark & 3 & 3 & 3.0 & 3 \\
\hline Germany & 13 & 11 & 12.0 & 11 \\
\hline Estonia & 12 & 22 & 17.0 & 17 \\
\hline Ireland & 25 & 25 & 25.0 & 24 \\
\hline Greece & 23 & 28 & 25.5 & 25 \\
\hline Spain & 11 & 18 & 14.5 & 12 \\
\hline France & 8 & 5 & 6.5 & 6 \\
\hline Croatia & - & 12 & - & - \\
\hline Italy & 15 & 17 & 16.0 & 14 \\
\hline Cyprus & 19 & 24 & 21.5 & 22 \\
\hline Latvia & 22 & 13 & 17.5 & 18 \\
\hline Lithuania & 20 & 20 & 20.0 & 21 \\
\hline Luxembourg & 16 & 23 & 19.5 & 20 \\
\hline Hungary & 14 & 8 & 11.0 & 10 \\
\hline Malta & 17 & 16 & 16.5 & 16 \\
\hline Netherlands & 7 & 7 & 7.0 & 8 \\
\hline Austria & 2 & 2 & 2.0 & 2 \\
\hline Poland & 24 & 21 & 22.5 & 23 \\
\hline Portugal & 18 & 14 & 16.0 & 14 \\
\hline Romania & 26 & 26 & 26.0 & 26 \\
\hline Slovenia & 4 & 9 & 6.5 & 6 \\
\hline Slovakia & 21 & 15 & 18.0 & 19 \\
\hline Finland & 5 & 4 & 4.5 & 4 \\
\hline Sweden & 1 & 1 & 1.0 & 1 \\
\hline United Kingdom & 10 & 19 & 14.5 & 12 \\
\hline
\end{tabular}

Source: Own preparation. 
Table 7.

Ranking of European Union countries by the synthetic sustainable development indicator in 2018 (top ten starting from place number 1)

\begin{tabular}{|c|c|c|c|}
\hline $\begin{array}{l}\text { Aggregate indicator } \\
\left(\text { TMRZ }_{\text {general }}\right)\end{array}$ & $\begin{array}{c}\text { Economic indicator } \\
\left(\text { TMRZ }_{\text {economic }}\right)\end{array}$ & $\begin{array}{c}\text { Social indicator } \\
\left(\text { TMRZ }_{\text {social }}\right)\end{array}$ & $\begin{array}{c}\text { Environemntal indicator } \\
\left(\text { TMRZ }_{\text {mean }}\right)\end{array}$ \\
\hline Sweden & Sweden & Sweden & Sweden \\
\hline Austria & Finland & Denmark & Latvia \\
\hline Denmark & Austria & Finland & Austria \\
\hline Finland & Denmark & Netherlands & Italy \\
\hline Czechia & Czechia & France & Croatia \\
\hline Slovenia & Belgium & Czechia & Spain \\
\hline France & Hungary & Austria & Portugal \\
\hline Netherlands & France & Luxemburd & Słovenia \\
\hline Belgium & Germany & Malta & Greece \\
\hline Hungary & Estonia & Stovenia & France \\
\hline
\end{tabular}

Source: Own preparation. 
